\title{
Microbacterium indicum sp. nov., isolated from a deep-sea sediment sample from the Chagos Trench, Indian Ocean
}

\author{
Correspondence \\ S. Shivaji \\ shivas@ccmb.res.in
}

\author{
S. Shivaji, ${ }^{1}$ Bhaskar Bhadra, ${ }^{1}$ R. Sreenivas Rao, ${ }^{1}$ Preeti Chaturvedi, ${ }^{1}$ \\ Pavan Kumar Pindi ${ }^{1}$ and Chandralata Raghukumar ${ }^{2}$ \\ ${ }^{1}$ Centre for Cellular and Molecular Biology, Uppal Road, Hyderabad 500 007, India \\ ${ }^{2}$ National Institute of Oceanography, Dona Paula, Goa 403 004, India
}

Two bacterial strains, $\mathrm{BBH}^{\top}$ and $\mathrm{BBH} 9$, were isolated from a deep-sea sediment sample collected from the Chagos Trench, Indian Ocean, at a depth of $5904 \mathrm{~m}$. The two strains were closely related in their $16 \mathrm{~S}$ rRNA gene sequences $(99.7 \%)$, belonged to one genomic species and were virtually identical at the phenotypic level. Microbacterium barkeri DSM $20145^{\top}$ was the nearest phylogenetic neighbour to the new isolates, with $16 \mathrm{~S}$ rRNA gene sequence similarity levels of $97.2-97.4 \%$. The new isolates exhibited levels of DNA-DNA relatedness of 32-34\% to $M$. barkeri and differed from it in a number of phenotypic characteristics. Therefore, it is suggested that strains $\mathrm{BBH}^{\top}{ }^{\top}$ and $\mathrm{BBH} 9$ represent a novel species of the genus Microbacterium, for which the name Microbacterium indicum sp. nov. is proposed. The type strain is $\mathrm{BBH}^{\top}$ (=LMG $23459^{\top}=$ IAM $15355^{\top}$ ).
A wide diversity of micro-organisms have been isolated from deep-sea sediments (Takami et al., 1997, 1999; Luna et al., 2004 and references therein). Raghukumar et al. (2004) reported on the microbial biodiversity in deep-sea sediment from the Chagos Trench, Indian Ocean, which forms part of the Chagos-Lacaddive ridge system, one of the deepest regions of the Indian Ocean. They isolated a fungus, Aspergillus sydowii, from a sub-seafloor sediment sample (3.4 m deep, 430000 years old) and also reported the presence of bacteria. In the present paper, we describe isolates recovered from a deep-sea sediment sample collected from the Chagos Trench at a depth of $5904 \mathrm{~m}$ (from a $50-70 \mathrm{~cm}$ section of a deep sediment core of $4.6 \mathrm{~m}$, approximately 50000 years old). The age of the sediment was inferred from the sedimentation rates in the Central Indian Ocean, which is reported to be approximately $1.0 \mathrm{~cm}$ per 1000 years (Gupta, 1999, 2002).

Deep-sea sediment samples were collected as described by Raghukumar et al. (2004) and sterile containers with the samples were stored at $4{ }^{\circ} \mathrm{C}$ for 1 year prior to the present analysis. Approximately $100 \mathrm{mg}$ of the sediment was suspended in $1 \mathrm{ml}$ of $2 \% \mathrm{NaCl}$, vortexed for $1 \mathrm{~min}$ and

The GenBank/EMBL/DDBJ accession numbers for the $16 \mathrm{~S}$ rRNA gene sequences of strains $\mathrm{BBH}^{\top}$ and $\mathrm{BBH} 9$ are $\mathrm{AM} 158907$ and AM286267, respectively.

Tables comparing the cellular fatty acid compositions and giving levels of DNA-DNA relatedness among strains $\mathrm{BBH}^{\top}$ and $\mathrm{BBH} 9$ and the type strains of Microbacterium barkeri and Microbacterium gubbeenense are available with the online version of this paper. the suspension was allowed to settle for $2 \mathrm{~min}$. Then, $100 \mu \mathrm{l}$ of the top aqueous layer was spread onto a plate of yeast-extract/peptone (YP) agar (per litre: $5 \mathrm{~g}$ yeast extract, $10 \mathrm{~g}$ peptone, $30 \mathrm{~g} \mathrm{NaCl}, 15 \mathrm{~g}$ agar). After 15 days incubation at $15{ }^{\circ} \mathrm{C}$, bacterial growth ranged from $4.4 \times 10^{3}$ to $7.6 \times 10^{3}$ c.f.u. per gram of sediment. Seven morphotypes were observed among more than 400 colonies, and five representatives from each colony morphotype were subjected to total protein analysis by SDS-PAGE as described by Laemmli (1970). By using this approach, the morphotype representatives were divided into five groups. Strains from four of these groups were identified as representing members of the genera Rothia, Micrococcus, Kocuria and Brachybacterium on the basis of phenotypic characteristics and preliminary $16 \mathrm{~S}$ rRNA gene sequence analysis (data not presented). Strains $\mathrm{BBH}^{\mathrm{T}}$ and $\mathrm{BBH}$, belonging to the fifth group, were characterized in detail to determine their taxonomic position. Reference strains Microbacterium barkeri JCM $1343^{\mathrm{T}}$ and Microbacterium gubbeenense JCM $12075^{\mathrm{T}}$ were used in experiments to determine the biochemical characteristics, fatty acid profile, polar lipid content and levels of DNA-DNA hybridization of the new strains.

Nutrient agar (HiMEDIA) was used for growth and maintenance of the strains and for determination of phenotypic, including chemotaxonomic, characteristics. To assess growth at different $\mathrm{pH}$ values, the $\mathrm{pH}$ of the sterile YP medium was adjusted from $\mathrm{pH} 4.0$ to 10.0 at $0.5 \mathrm{pH}$ units by using either $0.1 \mathrm{M} \mathrm{HCl}$ or $\mathrm{NaOH}$. For tests of salt tolerance, $1,3,6,8$ and $10 \%(\mathrm{w} / \mathrm{v}) \mathrm{NaCl}$ was added 
to YP medium lacking $\mathrm{NaCl}$. Results were scored after $72 \mathrm{~h}$ incubation at $22{ }^{\circ} \mathrm{C}$. A Leitz Diaplan phase-contrast microscope was used to ascertain the morphology and motility of the strains. Utilization of various carbon compounds as sole carbon source was tested at $22{ }^{\circ} \mathrm{C}$ for 15 days in mineral liquid medium as described by Reddy et al. (2000). Other physiological and biochemical characteristics were determined following the methods of Holding \& Collee (1971) and Smibert \& Krieg (1994). It was found that the two new isolates exhibited many similar phenotypic characteristics (see Table 1 and under the species description below) but were not identical. Strain

Table 1. Comparison of the phenotypic characteristics of strains BBH6 ${ }^{\top}$ and BBH9, Microbacterium barkeri JCM $1343^{\top}$ and Microbacterium gubbeenense JCM $12075^{\top}$

The four strains are positive for nitrate reduction, $\beta$-galactosidase and aesculin hydrolysis, but negative for catalase, oxidase, urease, lysine decarboxylase, ornithine decarboxylase, phenylalanine deamination, Voges-Proskauer reaction, indole production and methyl red test. All produced acid from D-glucose, fructose, L-arabinose, D-arabinose, D-xylose, D-cellobiose, maltose, trehalose, melezitose and sucrose. All four are able to utilize D-glucose, D-fructose, D-galactose, L-arabinose, D-cellobiose, lactose, maltose, sucrose, acetate, L-serine, L-arginine and L-lysine, but not erythritol, adonitol, $\alpha$-keto-glutarate, lactate, L-proline, L-cystine, L-isoleucine, L-aspartic acid or L-tyrosine as the sole carbon source. Menaquinones found are MK11 and MK12. All are sensitive to amikacin $(30 \mu \mathrm{g})$, cefuroxime $(30 \mu \mathrm{g})$, rifampicin $(25 \mu \mathrm{g})$, bacitracin $(10 \mu \mathrm{g})$, roxithromycin $(30 \mu \mathrm{g})$, tobramycin $(15 \mu \mathrm{g})$, gentamicin $(30 \mu \mathrm{g})$, erythromycin $(15 \mu \mathrm{g})$, ciprofloxacin $(30 \mu \mathrm{g})$, chloramphenicol $(30 \mu \mathrm{g})$ and kanamycin $(30 \mu \mathrm{g})$, but resistant to nalidixic acid $(30 \mu \mathrm{g})$. PG, Phosphatidylglycerol; DPG, diphosphatidylglycerol, PI, phosphatidylinositol. +, Positive; -, negative; S, sensitive; R, resistant.

\begin{tabular}{|c|c|c|c|}
\hline Phenotypic characteristic & Strains $\mathrm{BBH}^{\mathrm{T}}$ and $\mathrm{BBH} 9$ & M. barkeri JCM $1343^{\mathrm{T}}$ & M. gubbeenense JCM $12075^{\mathrm{T}}$ \\
\hline Colony size & $1.5-2 \mathrm{~mm}$ & $2-2.5 \mathrm{~mm}$ & $0.5-1 \mathrm{~mm}$ \\
\hline Colony colour & Pale yellow & Yellow & Pale yellow \\
\hline Growth temperature range $\left({ }^{\circ} \mathrm{C}\right)$ & $8-30$ & $15-30$ & $8-30$ \\
\hline Optimum temperature $\left({ }^{\circ} \mathrm{C}\right)$ & 22 & 28 & 28 \\
\hline Growth $\mathrm{pH}$ range & $5-9$ & $5-11$ & $5-10$ \\
\hline $\mathrm{NaCl}$ tolerance $(6 \%)$ & + & - & + \\
\hline $\mathrm{NaCl}$ tolerance $(8 \%)$ & - & - & + \\
\hline Lipase & - & + & - \\
\hline Amylase & - & + & - \\
\hline \multicolumn{4}{|l|}{ Acid production from: } \\
\hline D-Galactose & - & + & + \\
\hline L-Rhamnose & - & + & + \\
\hline Mannose & - & + & + \\
\hline Sorbitol & - & + & + \\
\hline \multicolumn{4}{|l|}{ Carbon source utilization: } \\
\hline L-Rhamnose & - & + & + \\
\hline D-Xylose & + & + & - \\
\hline L-Xylose & + & - & - \\
\hline D-Raffinose & + & - & - \\
\hline Mannose & - & + & + \\
\hline D-Ribose & + & - & - \\
\hline Melezitose & + & + & - \\
\hline Inositol & + & - & - \\
\hline Mannitol & + & - & + \\
\hline D-Glucuronate & - & - & + \\
\hline Malonate & + & + & - \\
\hline Citrate & - & + & + \\
\hline L-Asparagine & + & + & - \\
\hline L-Alanine & - & + & - \\
\hline \multicolumn{4}{|c|}{ Sensitivity to antibiotic ( $\mu$ g per disc): } \\
\hline Penicillin $(10 \mu \mathrm{g})$ & S & $\mathrm{R}$ & S \\
\hline Ampicillin $(25 \mu \mathrm{g})$ & $\mathrm{R}$ & $\mathrm{R}$ & S \\
\hline Polar lipids & PG, PI & PG, PI & PG, DPG, PI \\
\hline Diamino acid in the cell wall & D-Orn & D-Orn ${ }^{*}$ & L-Lys $\dagger$ \\
\hline Peptidoglycan type & $\mathrm{B} 2 \beta$ & $\mathrm{B} 2^{*}$ & $\mathrm{~B} 1 \dagger$ \\
\hline DNA G $+C$ content $(\mathrm{mol} \%)$ & 65.5 & 68.3 & 71.6 \\
\hline
\end{tabular}

All the data were acquired in the present study, except ${ }^{\star}$ Takeuchi \& Hatano (1998) and †Brennan et al. (2001). 


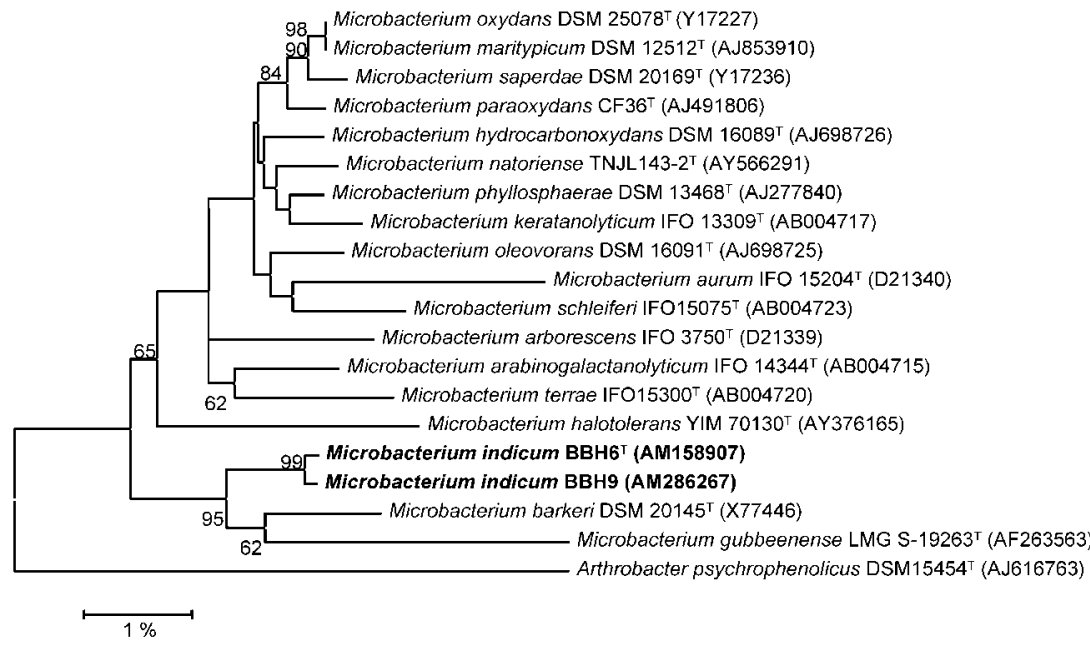

Fig. 1. Neighbour-joining tree based on $16 \mathrm{~S}$ rRNA gene sequences showing the phylogenetic relationship between strains $\mathrm{BBH}^{\top}$ and $\mathrm{BBH} 9$ and other closely related species of the genus Microbacterium. Bootstrap values (>50\%), expressed as percentages of 1000 replications, are given at the branching points. Accession numbers are given in parentheses. Bar, one substitution per $100 \mathrm{nt}$.
$\mathrm{BBH}^{\mathrm{T}}$ differed from $\mathrm{BBH} 9$ based on its ability to produce acid from D-glucosamine and lactose and by its inability to assimilate L-aspartate or L-tyrosine as a sole carbon and energy source.

Menaquinones and polar lipids were determined in freezedried cells. Menaquinones were purified by preparative TLC (Collins, 1994) and were identified via MS (Komagata \& Suzuki, 1987). Polar lipids were analysed according to the procedure of Minnikin et al. (1975) by using pure lipids as standards. Whole-cell sugars of strain $\mathrm{BBH}^{\mathrm{T}}$ were determined by TLC (Staneck \& Roberts, 1974) in samples prepared following the recommendations of Brennan et al. (2001). DNA was isolated according to the procedure of Marmur (1961) and the DNA G+C content was determined from the melting point $\left(T_{\mathrm{m}}\right)$ curves (Sly et al., 1986) obtained by using a Lambda 2 UV-vis spectrophotometer (Perkin Elmer) equipped with the Templab 2.0 software package (Perkin Elmer). Results of the above experiments are reported in the species description below and/or in Table 1. Cell walls were prepared from $500 \mathrm{mg}$ (dry weight) cell mass and purified according to Komagata \& Suzuki (1987). Amino acids and peptides in the cell wall were analysed by two-dimensional TLC on cellulose plates by using the solvent systems described by Schleifer \& Kandler (1972). The presence of L-Hse, D-Glu and D-Orn in the hydrolysed cell wall was detected by HPLC (Kageyama et al., 2006). The peptidoglycan of strains $\mathrm{BBH}^{\mathrm{T}}$ and $\mathrm{BBH} 9$ was of $\mathrm{B} 2 \beta$ type [(L-Hse)-D-Glu-Gly-D-Orn] (Schleifer \& Kandler, 1972).

Fatty acids were analysed as described by Reddy et al. (2002) in cells grown in trypticase soy agar (M322; HiMEDIA) at $28{ }^{\circ} \mathrm{C}$ and harvested in the exponential phase $\left(24 \mathrm{~h}\right.$ ). Fatty acids of strain $\mathrm{BBH}^{\mathrm{T}}$ (anteiso- $\mathrm{C}_{13: 0}$, $0.2 \%$; iso- $\mathrm{C}_{15: 0}, 6.6 \% ; \mathrm{C}_{15: 0}, 1.5 \%$; anteiso- $\mathrm{C}_{15: 0}, 25.3 \%$; iso- $\mathrm{C}_{16: 0}, 36.7 \% ; \mathrm{C}_{16: 0}, 15.2 \%$; anteiso- $\mathrm{C}_{17: 0}, 14.3 \%$ ) were typical of the genus Microbacterium, but differed from those of M. barkeri and M. gubbeenense in the proportions of the predominant components (see Supplementary Table S1 available in IJSEM Online).
Genomic DNA was isolated from freshly grown culture following the methods of Sambrook et al. (1989). The $16 \mathrm{~S}$ rRNA genes of the isolates were amplified, purified and sequenced according to Reddy et al. (2000). Alignment was performed with related sequences retrieved from the GenBank database by using CLUSTAL_X (Thompson et al., 1997) and corrected manually. A neighbourjoining phylogenetic tree (Saitou \& Nei, 1987) was constructed by using MEGA 3.1 (Kumar et al., 2004) based on evolutionary distances determined with Kimura's two-parameter model (Kimura, 1980). Bootstrap analysis (Felsenstein, 1985) was performed for 1000 replications.

$16 \mathrm{~S}$ rRNA gene sequence similarity between strains $\mathrm{BBH}^{\mathrm{T}}$ and $\mathrm{BBH} 9$ was $99.7 \%$; their nearest phylogenetic neighbour was M. barkeri DSM $20145^{\mathrm{T}}$, with levels of similarity of 97.2 and $97.4 \%$, respectively. The two new strains formed a robust clade with $M$. barkeri and $M$. gubbeenense with bootstrap support of $95 \%$ (Fig. 1). DNA-DNA dot-blot hybridization experiments were performed with a DIG DNA Labelling and Detection kit (Roche Diagnostics) as described by Bhadra et al. (2005). Strains BBH6 ${ }^{\mathrm{T}}$ and $\mathrm{BBH} 9$ showed $92 \%$ DNA-DNA relatedness to each other. However, the two new strains exhibited levels of DNA-DNA relatedness of $32-34 \%$ to $M$. barkeri and $M$. gubbeenense (see Supplementary Table S2 available in IJSEM Online), a level well below the $70 \%$ value accepted as the cut-off point for species delineation (Wayne et al., 1987). Therefore, based on the differences observed in the phenotypic and chemotaxonomic characteristics of strains $\mathrm{BBH}^{\mathrm{T}}$ and $\mathrm{BBH} 9$ with $M$. barkeri and M. gubbeenense (Table 1), it is suggested that they be classified as two strains of a novel species of the genus Microbacterium, for which the name Microbacterium indicum sp. nov. is proposed.

\section{Description of Microbacterium indicum sp. nov.}

Microbacterium indicum (in.di'cum. L. neut. adj. indicum pertaining to India). 
On YP agar after 2 days incubation at $22{ }^{\circ} \mathrm{C}$, forms circular, pale yellow colonies with an entire margin. Cells are Gram-positive rods. Growth occurs between 8 and $30{ }^{\circ} \mathrm{C}$, but not at 5 or $37{ }^{\circ} \mathrm{C}$. Growth occurs between pH 5 and 9 , but not at $\mathrm{pH} 4$ or 11 . Tolerates up to $6 \%(\mathrm{w} / \mathrm{v})$ $\mathrm{NaCl}$ at $\mathrm{pH}$ 6.8. Whole-organism sugars are rhamnose, galactose and glucose. Major menaquinones are MK11 and MK12. Polar lipids are phosphatidylglycerol and phosphatidylinositol. Cells contain type B $2 \beta$ peptidoglycan and the diamino acid present in the cell wall is D-Orn. Other phenotypic characteristics are as given in Table 1.

The type strain, $\mathrm{BBH6}^{\mathrm{T}}$ (=LMG $23459^{\mathrm{T}}=\mathrm{IAM} 15355^{\mathrm{T}}$ ), was isolated from a $50-70 \mathrm{~cm}$ section of a deep-sea sediment core of $4.6 \mathrm{~m}$ length obtained from the Chagos Trench, Indian Ocean, at a water depth of $5904 \mathrm{~m}$.

\section{Acknowledgements}

We would like to thank the National Centre for Antarctic and Ocean Research, Goa, India, for financial support to S.S. We are also thankful to Dr Rahul Sharma, National Institute of Oceanography, Goa, India, and the Department of Ocean Development, Government of India, for financial support for the collection of deep-sea sediments.

\section{References}

Bhadra, B., Roy, P. \& Chakraborty, R. (2005). Serratia ureilytica sp. nov., a novel urea-utilizing species. Int J Syst Evol Microbiol 55, 2155-2158.

Brennan, N. M., Brown, R., Goodfellow, M., Ward, A. C., Beresford, T. P., Vancanneyt, M., Cogan, M. C. \& Fox, P. F. (2001). Microbacterium gubbeenense sp. nov. from the surface of a smearripened cheese. Int J Syst Evol Microbiol 51, 1969-1976.

Collins, M. D. (1994). Isoprenoid quinones. In Chemical Methods in Prokaryotic Systematics, pp. 265-309. Edited by M. Goodfellow \& A. G. O'Donnell. Chichester: Wiley.

Felsenstein, J. (1985). Confidence limits on phylogenies: an approach using the bootstrap. Evolution 39, 783-791.

Gupta, S. M. (1999). Radiolarian monsoonal index Pyloniid group responds to astronomical forcing in the last $\sim 500,000$ years: evidence from the Central Indian Ocean. Man and Environ 24, 99-107.

Gupta, S. M. (2002). Pyloniid stratigraphy - a new tool to date tropical radiolarian ooze from the central tropical Indian Ocean. Mar Geol 184, 85-93.

Holding, A. J. \& Collee, J. G. (1971). Routine biochemical tests. Methods Microbiol 6A, 2-32.

Kageyama, A., Takahashi, Y. \& Omura, S. (2006). Microbacterium deminutum sp. nov., Microbacterium pumilum sp. nov. and Microbacterium aoyamense sp. nov. Int J Syst Evol Microbiol 56, 2113-2117.

Kimura, M. (1980). A simple method for estimating evolutionary rates of base substitutions through comparative studies of nucleotide sequences. J Mol Evol 16, 111-120.

Komagata, K. \& Suzuki, K. (1987). Lipid and cell wall analysis in bacterial systematics. Methods Microbiol 19, 161-207.

Kumar, S., Tamura, K. \& Nei, M. (2004). MEGA3.1: integrated software for molecular evolutionary genetics analysis and sequence alignment. Brief Bioinform 5, 150-163.
Laemmli, U. K. (1970). Cleavage of structural proteins during the assembly of head of bacteriophage T4. Nature 227, 680-685.

Luna, G. M., Dell'Anno, A., Giuliano, L. \& Danovaro, R. (2004). Bacterial diversity in deep Mediterranean sediments: relationship with the active bacterial fraction and substrate availability. Environ Microbiol 6, 745-753.

Marmur, J. (1961). A procedure for the isolation of deoxyribonucleic acid from microorganisms. J Mol Biol 3, 208-218.

Minnikin, D. E., Alshamaony, L. \& Goodfellow, M. (1975). Differentiation of Mycobacterium, Nocardia and related taxa by thin-layer chromatographic analysis of whole-organism methanolysates. J Gen Microbiol 88, 200-204.

Raghukumar, C., Raghukumar, S., Sheelu, G., Gupta, S. M., Bagender, B. \& Rao, B. R. (2004). Buried in time: culturable fungi in a deep-sea sediment core from the Chagos Trench, Indian Ocean. Deep Sea Res 51, 1759-1768.

Reddy, G. S. N., Aggarwal, R. K., Matsumoto, G. I. \& Shivaji, S. (2000). Arthobacter flavus sp. nov., a psychrophilic bacterium isolated from a pond in McMurdo Dry Valley, Antarctica. Int J Syst Evol Microbiol 50, 1553-1561.

Reddy, G. S. N., Prakash, J. S. S., Vairamani, M., Prabhakar, S., Matsumoto, G. I. \& Shivaji, S. (2002). Planococcus antarcticus and Planococcus psychrophilus spp. nov. isolated from cyanobacterial mat samples collected from ponds in Antarctica. Extremophiles 6, 253-262.

Saitou, N. \& Nei, M. (1987). The neighbor-joining method: a new method for reconstructing phylogenetic trees. Mol Biol Evol 4, 406-425.

Sambrook, J., Fritsch, E. F. \& Maniatis, T. (1989). Molecular Cloning: a Laboratory Manual, 2nd edn. Cold Spring Harbor, NY: Cold Spring Harbor Laboratory Press.

Schleifer, K. H. \& Kandler, O. (1972). Peptidoglycan types of bacterial cell walls and their taxonomic implications. Bacterial Rev 36, 407-477.

Sly, L. I., Blackall, L. L., Kraat, P. C., Tian-Shen, T. \& Sangkhobol, V. (1986). The use of second derivative plots for the determination of mol\% guanine plus cytosine of DNA by the thermal denaturation method. J Microbiol Methods 5, 139-156.

Smibert, R. M. \& Krieg, N. R. (1994). Phenotypic characterization: In Methods for General and Molecular Bacteriology, pp. 607-654. Edited by P. Gerhardt, R. G. E. Murray, W. A. Wood \& N. R. Krieg. Washington, DC: American Society for Microbiology.

Staneck, J. L. \& Roberts, G. D. (1974). Simplified approach to identification of aerobic actinomycetes by thin-layer chromatography. Appl Microbiol 28, 226-231.

Takami, H., Inoue, A., Fuji, F. \& Horikoshi, K. (1997). Microbial flora in the deepest sea mud of the Mariana Trench. FEMS Microbiol Rev 152, 279-285.

Takami, H., Kobata, K., Nagahama, T., Kobayashi, H., Inoue, A. \& Horikoshi, K. (1999). Biodiversity in deep-sea sites located near the south part of Japan. Extremophiles 3, 97-102.

Takeuchi, M. \& Hatano, K. (1998). Union of the genera Microbacterium Orla-Jensen and Aureobacterium Collins et al. in a redefined genus Microbacterium. Int J Syst Bacteriol 48, 739-747.

Thompson, J. D., Gibson, T. J., Plewniak, F., Jeanmougin, F. \& Higgins, D. G. (1997). The CLUSTAL_X windows interface: flexible strategies for multiple sequence alignment aided by quality analysis tools. Nucleic Acids Res 25, 4876-4882.

Wayne, L. G., Brenner, D. J., Colwell, R. R., Grimont, P. A. D., Kandler, O., Krichevsky, M. I., Moore, L. H., Moore, W. E. C., Murray, R. G. E. \& other authors (1987). International Committee on Systematic Bacteriology. Report of the ad hoc committee on reconciliation of approaches to bacterial systematics. Int J Syst Bacteriol 37, 463-464. 